\section{Comparison of Purification Effect and Nutrient Absorption of Three Grasses on Eutrophic Water}

\author{
Fang Xu, Junqin Zong, Jingbo Chen, Jianjian Li, Dandan Li, and \\ Jianxiu Liu \\ Institute of Botany, Jiangsu Province \& Chinese Academy of Sciences, \\ Nanjing 210014, China
}

\author{
Fang Xu \\ Xuzhou Jiuzhou Landscape Co., LTD., Xuzhou 221000, China
}

Additional index words. purification of eutrophic water, grasses, nitrogen, phosphorus, ecological restoration

\begin{abstract}
A static experiment in greenhouse was conducted to investigate the growth of three grasses in high and medium eutrophic water and the effects of their removal on ammonia nitrogen $\left(\mathrm{NH}_{4}{ }^{+}-\mathrm{N}\right)$, nitrate nitrogen $\left(\mathrm{NO}_{3}{ }^{-}-\mathrm{N}\right)$, total nitrogen (TN), total phosphorus (TP), and the chemical oxygen demand (COD), and compared with cattail (Typha angustifolia). The results showed that 1) the removal efficiency of $\mathrm{NH}_{4}^{+}-\mathrm{N}$, $\mathrm{NO}_{3}{ }^{-}-\mathrm{N}$, TN, TP, and COD treated by the four plants in eutrophic water were significantly higher than that in non-plant water. With the extension of treatment time, the concentrations of $\mathrm{NH}_{4}^{+}-\mathrm{N}, \mathrm{NO}_{3}{ }^{-}-\mathrm{N}, \mathrm{TN}, \mathrm{TP}$, and $\mathrm{COD}$ in the eutrophic water decreased first and then tend to be stable. 2) Cynodon dactylon 'Tifton 85' (C. dactylon 'Tifton 85'), Cortaderia selloana 'Pumila' (C. selloana 'Pumila') and $T$. angustifolia absorbed more than $95.7 \%$ and $88.6 \%$ of TN and TP in eutrophic water, and accumulate more than $89.5 \%$ and $82.0 \%$ in plants, respectively. However, the ratio of Cortaderia selloana 'Silver Comet' (C. selloana 'Silver Comet') was significantly lower. 3) The high abilities of these three plants to purify eutrophic water may be directly related to their rapid growth. 4) The comprehensive purification ability of the four plants to eutrophic was significantly different, in the order of $C$. dactylon 'Tifton $\mathbf{8 5}^{\prime}>C$. selloana 'Pumila' $\approx T$. angustifolia $>C$. selloana 'Silver Comet'. These results indicated that $C$. dactylon 'Tifton $85^{\prime}$ ' and $C$. selloana 'Pumila' can be used as alternative plants to $T$. angustifolia for the purification of eutrophic water. The results of this study can provide new materials and ideas for phytoremediation.
\end{abstract}

With the increase of industrial and domestic sewage and agricultural fertilizers emissions, nitrogen $(\mathrm{N})$, phosphorus $(\mathrm{P})$, and other nutrients discharged into the lake are constantly increasing, making more and more

Received for publication 16 Aug. 2021. Accepted for publication 9 Sept. 2021.

Published online 26 October 2021

This work was supported by Water Conservancy Science and Technology Foundation of Jiangsu Province (2019061); the National Natural Science Foundation of China (31771870); the Water Research Programs Foundation of Ministry of Science \& Technology, China (2012ZX07101).

F.X. and J.Z. designed the research and carried out the manuscript editing. F.X., J.Z., and J.C. designed and performed the experiments. J.Z. and J.J.L. carried out statistical analysis. J.C. and J.X.L. provided the Manuscript review. F.X. and J.Z. completed the manuscript final version approval. All authors have read and approved the final manuscript.

The authors declare that the research was conducted in the absence of any commercial or financial relationships that could be construed as a potential conflict of interest.

J.Z. is the corresponding author. E-mail: zongjq1980@163.com.

This is an open access article distributed under the CC BY-NC-ND license (https://creativecommons. org/licenses/by-nc-nd/4.0/). lakes eutrophic (Lian et al., 2018; Yao et al., 2011). Eutrophication has a significant negative impact on the overall water quality and biodiversity of the lakes, leading to the proliferation of harmful cyanobacterial blooms, contaminating water supplies, destroying food webs, driving hypoxia, reducing biodiversity, and producing secondary metabolites toxic to consumers (Jóźwiakowski et al., 2017; Qin et al., 2015). As a result of the serious eutrophication pollution and water shortage in different degrees, the treatment technology of water pollution has been paid more and more attention (Wei, 2021).

Studies have highlighted the importance of constructed wetlands in water purification, which could achieve efficient water purification through direct absorption of wetland plants, soil filtration, and microbial decomposition (Muhammad et al., 2020). It is more in line with the requirements of sustainable development and has been widely used in the repair of various types of sewage (Bouchama et al., 2016). Recently, the selected plant for constructed wetlands are mainly concentrated in aquatic plants, such as reed, cattail (Typha angustifolia, T. angustifolia), cress, and others because of their long growing period, large biomass, and strong vitality (Lu et al., 2016; Ojoawo et al., 2015; Razmkhah et al., 2016).
However, aquatic plant technology has limitations, such as different aquatic plants have survival thresholds for different pollution factors, and unreasonable plant community configuration under different environments and seasons, and so on. Bermuda grass (Cynodon dactylon L.) and pampas grass (Cortaderia selloana) are excellent ornamental grass varieties with high absorption rate, strong tolerance, high aboveground biomass, and easy cultivation ( $\mathrm{Li}$ et al., 2011; Saber et al., 2018; Zhang et al., 2019). One Bermuda grass variety, Tifton 85 bermudagrass $(C$. dactylon 'Tifton 85 '), has been proved to grow well under sewage irrigation because of its high response to nitrogen and nutrient absorption rate (Fonseca et al., 2007). Pampas grass is a kind of perennial herbaceous plant, and varieties such as Cortaderia selloana 'Pumila' (C. selloana 'Pumila') and Cortaderia selloana 'Silver Comet' $(C$. selloana 'Silver Comet') are highly adaptable to the environment and can keep green in cold winter (Vourlitis and Kroon, 2013). C. selloana 'Pumila' also has strong photosynthetic capacity and high temperature resistance ability, could play more ecological benefits as high carbon sequestration plants in wetlands (Meng et al., 2018). The earlier studies indicate that Bermuda grass and pampas grass have potential application in water purification, but there is still a lack of systematic research on their purification ability to eutrophic water.

In this study, $C$. dactylon 'Tifton 85', $C$. selloana 'Pumila', and C. selloana 'Silver Comet' were selected to systematically evaluate the removal capacities of $\mathrm{NH}_{4}{ }^{+}-\mathrm{N}$, $\mathrm{NO}_{3}{ }^{-}-\mathrm{N}, \mathrm{TN}, \mathrm{TP}$, and $\mathrm{COD}$ in different eutrophic water. And their purification ability was compared with the aquatic plant $T$. angustifolia (control plant) with excellent purification ability (Ghosh and Gopal, 2010; Lim, 2007; Xu et al., 2011). The findings of this study are expected to screen out the grasses with good purification effect and wide adaptability, providing new candidate materials for the establishment of constructed wetlands and/ or eutrophication treatment of water bodies.

\section{Materials and Methods}

Preparation of materials. The experiment was conducted in a green house in the Institute of Botany, Jiangsu Province and Chinese Academy of Sciences, Nanjing (lat. $32^{\circ} 02^{\prime}$ $\mathrm{N}$, long. $118^{\circ} 28^{\prime} \mathrm{E}$, altitude $30 \mathrm{~m}$ ) from 23 May to 22 July 2017 . The daily light intensity ranged from 358.2 to $883.8 \mu \mathrm{mol} \cdot \mathrm{m}^{-2} \cdot \mathrm{s}^{-1}$, the maximum average daily temperature was $33.2^{\circ} \mathrm{C}$, and the minimum average daily temperature was $21.1^{\circ} \mathrm{C}$.

C. dactylon 'Tifton 85' was collected and preserved in our laboratory. C. selloana 'Pumila', C. selloana 'Silver Comet', and $T$. angustifolia were bought from Jinghe Company, Shanghai. A $20-\mathrm{cm}$ segment with an axillary bud of $C$. dactylon 'Tifton 85 ' was selected as the research material, and other plants were individual plants. Cleaned all the root of the plants, rolled up the stems with a sponge and fixed them on the circular foam board $(25 \mathrm{~cm}$ in diameter) with holes. Using 
nonporous flowerpots (with a diameter of 27 $\mathrm{cm}$, a height of $25 \mathrm{~cm}$, and a volume of $5 \mathrm{~L}$ ) as water containers, the foam boards with plants floating on the water serve as simulated ecological floating beds. To ensure roughly the same initial biomass, the number of $T$. angustifolia, $C$. selloana 'Silver Comet', C. selloana 'Pumila', and $C$. dactylon 'Tifton 85 ' on each foam board was 3, 2, 2, and 4, respectively. All plants were precultured in tap water for 2 weeks and treated with eutrophic water after rooting well.

In this study, two different concentrations of eutrophic water were simulated by adding a certain amount of nutrients into pollute water from Suojin Village River in Nanjing. The concentrations of $\mathrm{NH}_{4}{ }^{+}-\mathrm{N}, \mathrm{NO}_{3}{ }^{-}-\mathrm{N}$, $\mathrm{TN}, \mathrm{TP}$, and COD in high-concentration eutrophic water were $11.56 \mathrm{mg} \cdot \mathrm{L}^{-1}, 7.12$ $\mathrm{mg} \cdot \mathrm{L}^{-1}, 25.50 \mathrm{mg} \cdot \mathrm{L}^{-1}, 2.53 \mathrm{mg} \cdot \mathrm{L}^{-1}$, and $63.20 \mathrm{mg} \cdot \mathrm{L}^{-1}$, respectively; the concentrations of $\mathrm{NH}_{4}{ }^{+}-\mathrm{N}, \mathrm{NO}_{3}{ }^{-}-\mathrm{N}, \mathrm{TN}, \mathrm{TP}$, and $\mathrm{COD}$ in medium-concentration eutrophic water were $7.44 \mathrm{mg} \cdot \mathrm{L}^{-1}, 4.51 \mathrm{mg} \cdot \mathrm{L}^{-1}, 15.34 \mathrm{mg} \cdot \mathrm{L}^{-1}$, $1.55 \mathrm{mg} \cdot \mathrm{L}^{-1}$, and $41.75 \mathrm{mg} \cdot \mathrm{L}^{-1}$, respectively. According to the evaluation standard of surface water quality and the evaluation standard of eutrophication degree in the Technical Specification for Surface Water Resources Quality Assessment issued by The Ministry of Water Resources of the People's Republic of China (2007), the two eutrophic water were classified as class V standard and severe eutrophication.

Experimental design. Two eutrophic water concentrations (high and medium), four plant treatments $(C$. dactylon 'Tifton 85 ', C. selloana 'Pumila', C. selloana 'Silver Comet', and T. angustifolia), and a blank control without plants were set up in this study. Four replicates were set up for each plant treatment. At the beginning of the experiment, $5 \mathrm{~L}$ eutrophic water was added to each pot, and the change of water index was continuously monitored, and the plants were harvested on day 16. During the experimental period, distilled water was added daily to supplement the water loss because of evaporation and plant transpiration.

Measurements and methods. About $15 \mathrm{~mL}$ water samples were taken every $4 \mathrm{~d}$ from the pot to determine the water quality indicators such as $\mathrm{NH}_{4}{ }^{+}-\mathrm{N}, \mathrm{NO}_{3}{ }^{-}-\mathrm{N}, \mathrm{TN}, \mathrm{TP}$, and $\mathrm{COD}$; the corresponding determination methods were from the State Environmental Protection Administration of China (2002). At the beginning and the end of the experiment, each plant material was sampled and oven-dried at $105^{\circ} \mathrm{C}$ for $30 \mathrm{~min}$, and then dried at $80^{\circ} \mathrm{C}$ for $72 \mathrm{~h}$ and weighed. The plant dry samples were used for measuring $\mathrm{N}$ and $\mathrm{P}$ contents according to the methods of $\mathrm{Lu}$ (2000).

Calculation. Nitrogen and phosphorus accumulation of plants were the total nitrogen and phosphorus at the end minus the total nitrogen and phosphorus at the beginning.

The calculation formula of removal rate $(R)$ of TN, TP, and COD was as follows:

$$
R=\left(C_{0}-C_{\mathrm{i}}\right) \div C_{0} \times 100 \%
$$

$C_{\mathrm{i}}$ was the concentration of $\mathrm{TN}, \mathrm{TP}$, and $\mathrm{COD}$ in the ith day; $C_{0}$ was the initial concentration of TN, TP, and COD.
The calculation formula of contribution rate of $\mathrm{N}\left(C_{\mathrm{N}}\right)$ and $\mathrm{P}\left(C_{\mathrm{P}}\right)$ was as follows:

$C_{N}=\mathrm{N}$ accumulation $\div\left(C_{0} \times V-C_{e} \times V\right) \times 100 \%$

$C_{P}=P$ accumulation $\div\left(C_{0} \times V-C_{\mathrm{e}} \times V\right) \times 100 \%$

$C_{\mathrm{e}}$ was the concentration of TN, TP at the end of experiment, $V=5 \mathrm{~L}$.

Statistical analysis. All data were analyzed using SPSS software (ver. 20.0; SPSS, Chicago, IL), and the results were presented as the sample means \pm SD $(n=4)$. Statistical analysis used an analysis of variance (ANOVA) followed by Duncan's test at a significance level of $\alpha=0.05$.

\section{Results}

Purification effects of different plants on $\mathrm{NH}_{4}{ }^{+}-\mathrm{N}$ and $\mathrm{NO}_{3}{ }^{-}-\mathrm{N}$ concentration in eutrophic water. The concentration of $\mathrm{NH}_{4}{ }^{+}-\mathrm{N}$ and $\mathrm{NO}_{3}{ }^{-}-\mathrm{N}$ in high and medium concentration eutrophic water treated by plants was significantly lower than that of control water (Fig. 1). With the extension of the experiment time, the $\mathrm{NH}_{4}{ }^{+}-\mathrm{N}$ concentration in each plant experiment showed a rapid decrease, then maintained a stable trend (Fig. 1A). Among them, the $\mathrm{NH}_{4}{ }^{+}-\mathrm{N}$ concentration in $C$. dactylon 'Tifton $85^{\prime}$ ' treated eutrophic water decreased the fastest, and was lower than $1.0 \mathrm{mg} \cdot \mathrm{L}^{-1}$ on the 4th day. The eutrophic water treated with C. selloana 'Silver Comet' showed the slowest decline, but there was no significant difference with other plants after $12 \mathrm{~d}$ of treatment. The change of $\mathrm{NO}_{3}{ }^{-}-\mathrm{N}$ concentration was consistent with that of $\mathrm{NH}_{4}{ }^{+}-\mathrm{N}$ (Fig. 1B). However, the $\mathrm{NO}_{3}{ }^{-} \mathrm{N}$ concentration of the water treated by $C$. selloana 'Silver Comet' was significantly lower than that of other plants. Even at the end of the experiment, the $\mathrm{NO}_{3}{ }^{-}-\mathrm{N}$ concentration in the high and medium concentration eutrophic water was still higher than 2.0 and $1.0 \mathrm{mg}$, respectively.

Purification effects of different plants on $T N$ concentration in eutrophic water. With the treatment time extended, the TN concentrations of the eutrophic water decreased significantly in different plants treatment (Fig. 2). After $16 \mathrm{~d}$ of treatment, the TN concentration of the high eutrophication level water treated by C. dactylon 'Tifton 85 ' was reduced to
$0.46 \mathrm{mg} \cdot \mathrm{L}^{-1}$ and converted the water to a noneutrophic level $\left(\mathrm{TN}<1.0 \mathrm{mg} \cdot \mathrm{L}^{-1}\right)$ and class II standard $\left(\mathrm{TN} \leq 0.5 \mathrm{mg} \cdot \mathrm{L}^{-1}\right)$. The $\mathrm{TN}$ concentration of the water treated by $C$. selloana 'Pumila' and T. angustifolia (1.03 and $1.02 \mathrm{mg} \cdot \mathrm{L}^{-1}$, respectively) reached to generate eutrophic level $\left(1.0 \leq \mathrm{TN}<2.0 \mathrm{mg} \cdot \mathrm{L}^{-1}\right)$ and class III standard $(0.5<\mathrm{TN} \leq 1.0$ $\left.\mathrm{mg} \cdot \mathrm{L}^{-1}\right)$. In contrast, the water treated by $C$. selloana 'Silver Comet' $\left(7.11 \mathrm{mg} \cdot \mathrm{L}^{-1}\right)$ was still belonging to moderate eutrophic level $\left(2.0 \leq \mathrm{TN}<9.0 \mathrm{mg} \cdot \mathrm{L}^{-1}\right)$. For medium-concentration eutrophic water, after treatment with $C$. dactylon 'Tifton 85 ' for $12 \mathrm{~d}$, the water converted to noneutrophic level, which was $4 \mathrm{~d}$ earlier than $C$. selloana 'Pumila' and T. angustifolia. However, the water treated by C. selloana 'Silver Comet' was still at the general eutrophic level $\left(1.83 \mathrm{mg} \cdot \mathrm{L}^{-1}\right)$ on day 16.

Purification effects of different plants on TP concentration in eutrophic water. After 16 $\mathrm{d}$ of treatment by different plants, the TP concentrations in eutrophic water also decreased significantly (Fig. 3). In the high eutrophication water, the TP concentration of treated by C. dactylon 'Tifton 85' $\left(0.04 \mathrm{mg} \cdot \mathrm{L}^{-1}\right)$ decreased to noneutrophic level and class II standard (TP $\left.<0.1 \mathrm{mg} \cdot \mathrm{L}^{-1}\right)$; the TP concentration in high eutrophic water treated by $C$. selloana 'Pumila' and $T$. angustifolia decreased to moderate eutrophic level $(0.2 \leq$ $\left.\mathrm{TP}<0.9 \mathrm{mg} \cdot \mathrm{L}^{-1}\right)$, whereas that of $C$. selloana 'Silver Comet' was still at severe eutrophic level ( $\left.\mathrm{TP} \geq 0.9 \mathrm{mg} \cdot \mathrm{L}^{-1}\right)$. In medium-concentration eutrophic water, the TP concentration treated by $C$. dactylon 'Tifton 85 ' $\left(0.04 \mathrm{mg} \cdot \mathrm{L}^{-1}\right)$ decreased to the noneutrophic level and class II standard on the day 8 , and 8 d earlier than C. selloana 'Pumila' and $T$. angustifolia. Nevertheless, the TP concentration treated by $C$. selloana 'Silver Comet' remained at a severe eutrophication level $\left(1.02 \mathrm{mg} \cdot \mathrm{L}^{-1}\right)$ until day 16.

Purification effects of different plants on $C O D$ concentration in eutrophic water. The COD changes in different eutrophic water are shown in Fig. 4. The COD concentrations in eutrophic water in C. dactylon 'Tifton 85' and $T$. angustifolia treatment was always lower than that of $C$. selloana 'Pumila' and C. selloana 'Silver Comet'. The four plants reduced the high-concentration eutrophic water to class $\mathrm{V}$ standard $(20 \leq \mathrm{COD}<30$
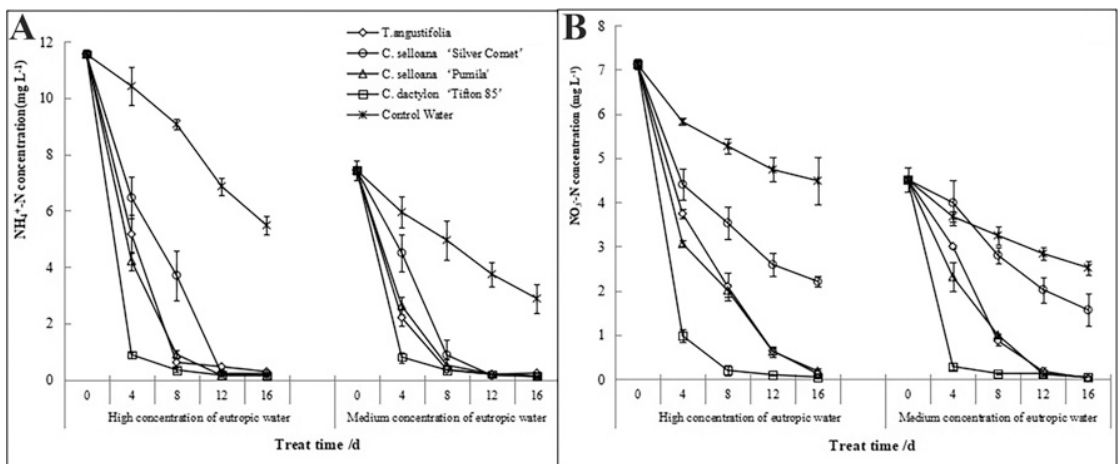

Fig. 1. Variations of $\mathrm{NH}_{4}{ }^{+}-\mathrm{N}(\mathbf{A})$ and $\mathrm{NO}_{3}{ }^{-}-\mathrm{N}(\mathbf{B})$ concentration in different eutrophic water treated with different plants. 


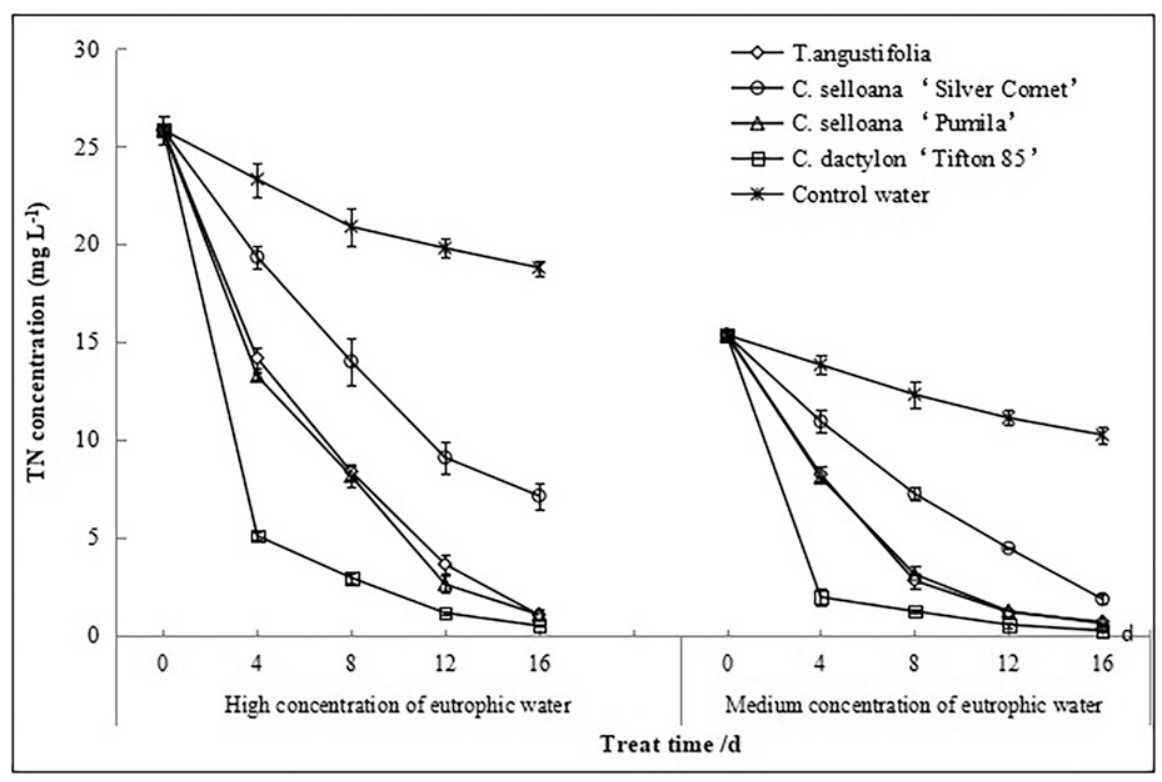

Fig. 2. Variations of total nitrogen (TN) concentration in different eutrophic water treated with different plants.

$\left.\mathrm{mg} \cdot \mathrm{L}^{-1}\right)$ on day 8 and class III standard $\left(15<\mathrm{COD}<20 \mathrm{mg} \cdot \mathrm{L}^{-1}\right)$ on day 16 . In medium-concentration eutrophic water, the COD concentration of $C$. dactylon 'Tifton 85' and $T$. angustifolia treatment deceased faster than that of $C$. selloana 'Pumila' and C. selloana 'Silver Comet'. However, there was no significant difference among the four plants after $12 \mathrm{~d}$ of purification, and all water reached class II standard on day 16 of purification. $\mathrm{NO}_{3}{ }^{-}-\mathrm{N}, \mathrm{TN}, \mathrm{TP}$, and $\mathrm{COD}$ by four plants. The removal rates of $\mathrm{NH}_{4}{ }^{+}-\mathrm{N}, \mathrm{NO}_{3}{ }^{-}-\mathrm{N}, \mathrm{TN}$, $\mathrm{TP}$, and COD of the four plants were significantly higher than those of the water without plants, and the differences among different plants were significant (Table 1). In high-concentration eutrophic water, $C$. dactylon 'Tifton 85 ' had the highest $\mathrm{NH}_{4}{ }^{+}-\mathrm{N}, \mathrm{NO}_{3}{ }^{-}-\mathrm{N}$,
Changes in the removal rates in $\mathrm{NH}_{4}^{+}-\mathrm{N}$,

TN, TP, and COD removal rates, and significantly higher than those of other plants. The $\mathrm{NH}_{4}{ }^{+}-\mathrm{N}, \mathrm{NO}_{3}{ }^{-}-\mathrm{N}, \mathrm{TN}$, and $\mathrm{TP}$ removal rates of $C$. selloana 'Pumila' were similar to that of $T$. angustifolia, but the COD removal rate was higher than that of $T$. angustifolia. In medium-concentration eutrophic water, $C$. dactylon 'Tifton 85' had the highest $\mathrm{NH}_{4}{ }^{+}-\mathrm{N}, \mathrm{NO}_{3}{ }^{-}-\mathrm{N}, \mathrm{TN}$, and TP remove rates in the first $8 \mathrm{~d}$, but there was no significant difference with $T$. angustifolia and $C$. selloana 'Pumila' after $12 \mathrm{~d}$ of treatment. In the eutrophic water with two concentrations, the $\mathrm{NH}_{4}{ }^{+}-\mathrm{N}, \mathrm{NO}_{3}{ }^{-}-\mathrm{N}, \mathrm{TN}, \mathrm{TP}$, and COD removal rates of $C$. selloana 'Silver Comet' were always the lowest. On the whole, the removal rate of $\mathrm{TN}$ and $\mathrm{TP}$ by plants in high-concentration eutrophic water was higher than that in medium-concentration eutrophic water, whereas the removal rate of COD was

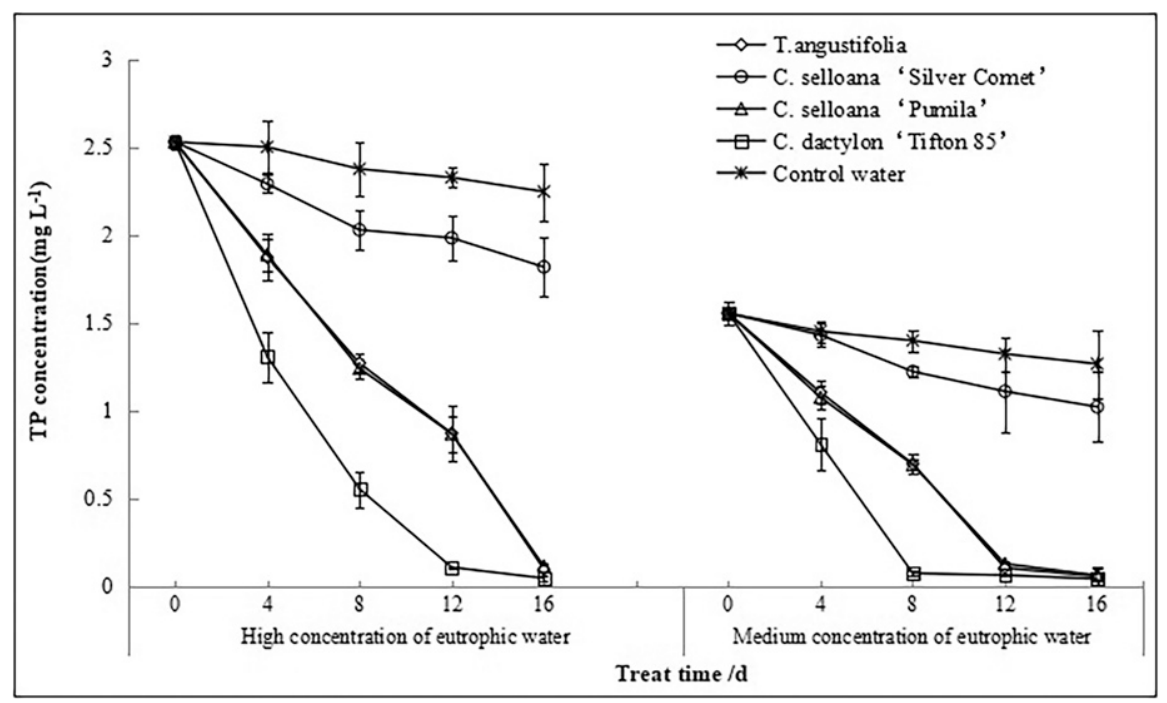

Fig. 3. Variations of total phosphorus (TP) concentration in different eutrophic water treated with different plants. lower than that in medium-concentration eutrophic water, but the difference was not significant.

Dry weight, $N$, and $P$ accumulation of different plants in eutrophic water. As can be seen from Table 2, the dry mass accumulation and increase rate of the four plants were significantly different, and the order from high to low was $C$. dactylon 'Tifton 85 ', $T$. angustifolia, $C$. selloana 'Pumila', and C. selloana 'Silver Comet'. In particular, the biomass of $C$. dactylon 'Tifton 85' increased by more than $100 \%$ in both high- and mediumconcentration eutrophic water. The plant $\mathrm{N}$ and $\mathrm{P}$ accumulation of $C$. dactylon 'Tifton $85^{\prime}$ was also the highest both in high- and medium-concentration eutrophic water, but there was no significant differences with $C$. selloana 'Pumila' and T. angustifolia. However, the $\mathrm{N}$ and $\mathrm{P}$ accumulation of the other three plants were all significantly higher than that of C. selloana 'Silver Comet'. In particular, the $\mathrm{P}$ accumulation of the three plants was more than three times higher than that of C. selloana 'Silver Comet' in the two eutrophic waters.

Contribution rate of $N$ and $P$ uptake by plants. The $\mathrm{N}$ accumulations of $C$. dactylon 'Tifton 85', T. angustifolia and C. selloana 'Pumila' all accounted for more than $93.0 \%$ of the $\mathrm{N}$ uptake from the high-concentration eutrophic water, which was significantly higher than $57.5 \%$ of $C$. selloana 'Silver Comet' (Table 2). The contribution of $\mathrm{N}$ uptake were similar in medium-concentration eutrophic water, but the $\mathrm{N}$ uptake contribution of $T$. angustifolia, and $C$. selloana 'Pumila' ( $90.6 \%$ and $89.5 \%$, respectively) was lower than that in high-concentration eutrophic water, while that of $C$. selloana 'Silver Comet' was higher than that in highconcentration eutrophic water $(66.5 \%)$. In high-concentration eutrophic water, there was no significant difference in $\mathrm{P}$ uptake contribution of the four plants, but that of $C$. dactylon 'Tifton 85 ' was the highest $(89.3 \%)$. However, in the medium-concentration eutrophic water, C. selloana 'Silver Comet' (67.4\%) contributed much less to $\mathrm{P}$ uptake than the other three plants.

\section{Discussion}

Aquatic plants are mostly used in the wastewater purification system of constructed wetland, because aquatic plants will take away a large amount of N, P, and other elements in the water during their growth ( $\mathrm{Li}$ et al., 2015; Rocio et al., 2018). The results of this study showed that $C$. dactylon 'Tifton $85^{\prime}$ had the strongest and fastest purification ability to purify eutrophic water. This was followed by $C$. selloana 'Pumila', whose effect was similar to that of $T$. angustifolia (Figs. 1-4). C. selloana 'Silver Comet' had the lowest purification ability on eutrophic water. The higher removal rates of $\mathrm{TN}, \mathrm{TP}$, and COD in C. dactylon 'Tifton 85 ' and $C$. selloana 'Pumila' may be directly related to their faster growth rate (Table 1), which also means that the eutrophic water can be continuously purified through continuous harvesting 


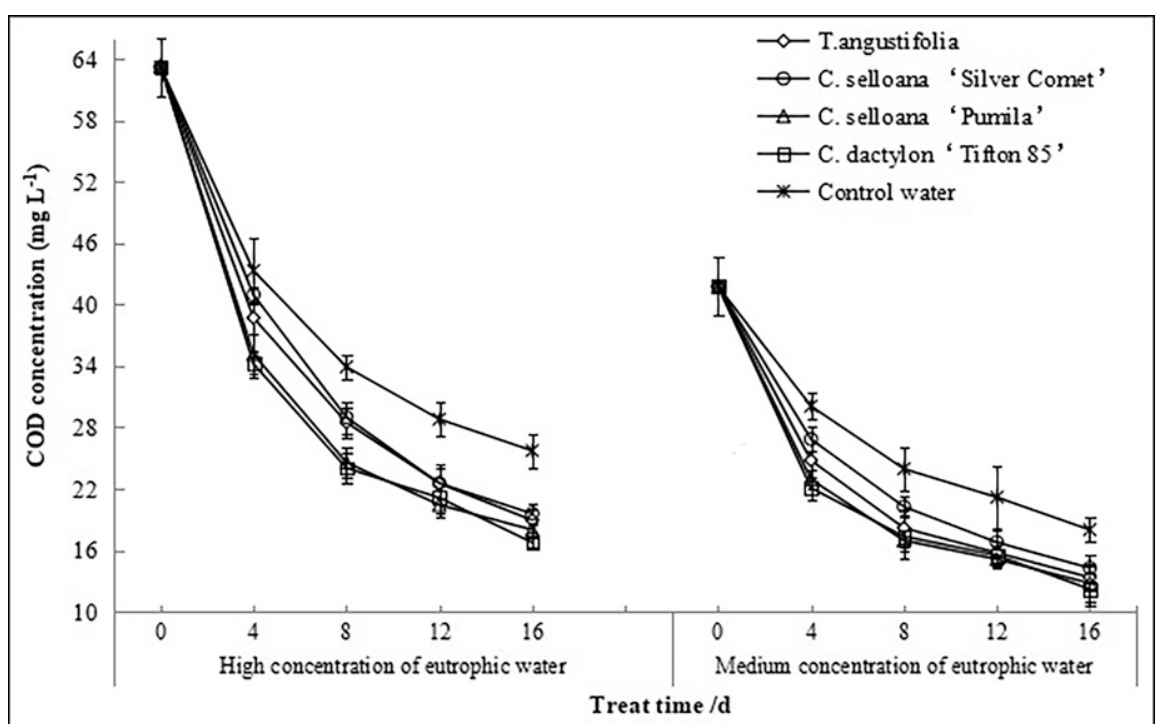

Fig. 4. Variations of chemical oxygen demand (COD) concentration in different eutrophic water treated with different plants.

(Zhu et al., 2011). In addition, C. dactylon 'Tifton $85^{\prime}$ ' is a high-quality forage grass that can be continuously cut to obtain economic value; $C$. selloana 'Pumila' has a good landscape effect. At present, the two grasses have been rarely reported in eutrophication treatment of water and have great potential and space for application.

The removal of $\mathrm{N}$ in constructed wetland mainly depends on the direct absorption of plants and the ammoniation, nitrification, and denitrification of microorganisms (Paredes et al., 2010). In this experiment, the TN removal rates of the four plants were more than $70 \%$ in different eutrophication water (Table 1), and more than $89.5 \%$ of TN was directly assimilated by the plants (except $C$. selloana 'Silver Comet') (Table 2). This indicated that the TN purification mainly depends on plant adsorption, which was similar to that of aquatic plants (Lu et al., 2018). This was inconsistent with the conclusion of several studies that plant absorption and storage only accounted for a small part of $\mathrm{N}$ removal, and most of which was removed by nitrification and denitrification under the action of microorganisms (Gersberg et al., 1986; Wu et al., 2013a). However, other studies have shown that the removal rate of $\mathrm{NH}_{4}{ }^{+}-\mathrm{N}$ by wetland plants is obviously higher than that of $\mathrm{NO}_{3}{ }^{-}$$\mathrm{N}$ (Wu et al., 2013a). In this experiment, the removal rate of $\mathrm{NH}_{4}{ }^{+}-\mathrm{N}$ was higher than that of $\mathrm{NO}_{3}{ }^{-}-\mathrm{N}$ in the first $12 \mathrm{~d}$ and lower than

Table 1. Total nitrogen (TN), total phosphorus (TP), and chemical oxygen demand (COD) removal rate of the four plant species in different eutrophic water.

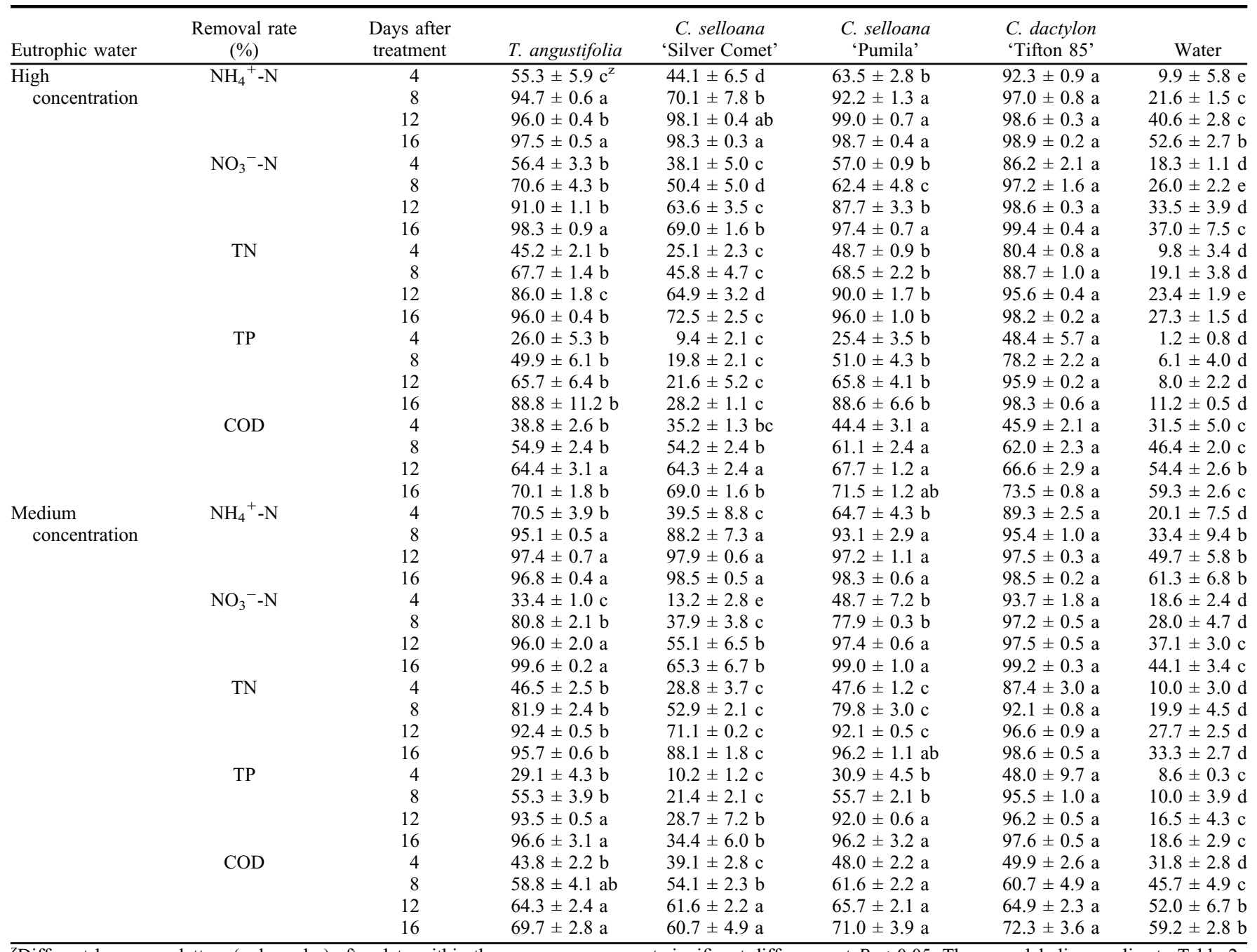

${ }^{\mathrm{z}}$ Different lowercase letters (a, b, and c) after data within the same row represent significant difference at $P<0.05$. The same labeling applies to Table 2 . 
Table 2. Dry mass, nitrogen $(\mathrm{N})$, and phosphorus $(\mathrm{P})$ accumulation and contribution of $\mathrm{N}$, and $\mathrm{P}$ absorption of the four plants in different eutrophic water.

\begin{tabular}{|c|c|c|c|c|c|c|c|}
\hline Eutrophic water & Plants & $\begin{array}{l}\text { Increase of plant } \\
\text { dry mass (g/pot) }\end{array}$ & $\begin{array}{c}\text { Increase rate of } \\
\text { plant dry mass } \\
(\%)\end{array}$ & $\begin{array}{c}\text { Plant N } \\
\text { accumulation } \\
(\mathrm{mg} / \mathrm{pot})\end{array}$ & $\begin{array}{c}\text { Plant P } \\
\text { accumulation } \\
\text { (mg/pot) }\end{array}$ & $\begin{array}{l}\text { Contribution of } \\
\mathrm{N} \text { absorption } \\
(\%)\end{array}$ & $\begin{array}{l}\text { Contribution of } \\
\text { P absorption (\%) }\end{array}$ \\
\hline \multirow{2}{*}{$\begin{array}{l}\text { High } \\
\quad \text { concentration }\end{array}$} & T. angustifolia & $225.5 \pm 11.1 \mathrm{~b}$ & 86.5 & $116.1 \pm 4.5 \mathrm{a}$ & $10.0 \pm 0.4 \mathrm{~b}$ & 93.7 & 82.0 \\
\hline & $\begin{array}{l}\text { C. selloana } \\
\text { 'Pumila' }\end{array}$ & $184.5 \pm 10.5 \mathrm{c}$ & 72.1 & $118.9 \pm 1.6 \mathrm{a}$ & $10.2 \pm 0.4 \mathrm{ab}$ & 96.0 & 84.0 \\
\hline \multirow{4}{*}{$\begin{array}{l}\text { Medium } \\
\quad \text { concentration }\end{array}$} & T. angustifolia & $201.5 \pm 8.5 b$ & 77.3 & $66.3 \pm 5.7 \mathrm{a}$ & $6.2 \pm 0.5 \mathrm{a}$ & 90.6 & 82.7 \\
\hline & $\begin{array}{l}\text { C. selloana } \\
\text { 'Silver } \\
\text { Comet' }\end{array}$ & $51.0 \pm 3.8 \mathrm{~d}$ & 19.0 & $44.8 \pm 1.7 \mathrm{~b}$ & $1.8 \pm 0.1 \mathrm{~b}$ & 66.5 & 67.4 \\
\hline & $\begin{array}{l}\text { C. selloana } \\
\text { 'Pumila' }\end{array}$ & $166.0 \pm 18.6 \mathrm{c}$ & 64.8 & $65.8 \pm 1.6 \mathrm{a}$ & $6.2 \pm 0.1 \mathrm{a}$ & 89.5 & 83.5 \\
\hline & $\begin{array}{l}\text { C. dactylon } \\
\text { 'Tifton } 85 \text { ' }\end{array}$ & $271.0 \pm 15.2 \mathrm{a}$ & 122.1 & $70.5 \pm 2.8 \mathrm{a}$ & $6.3 \pm 0.2 \mathrm{a}$ & 93.5 & 82.8 \\
\hline
\end{tabular}

that of $\mathrm{NO}_{3}{ }^{-}-\mathrm{N}$ on day 16 , indicating that the higher contribution rate of $\mathrm{N}$ uptake by plants may be related to both the direct absorption of $\mathrm{NH}_{4}{ }^{+}-\mathrm{N}$ and the nitrification of microorganisms.

$P$ removal process in constructed wetland system is accomplished through physical and chemical action of substrate, plant absorption, and microbial assimilation (Wu et al., 2013b). This study showed that the TP removal rate in the non-plant control water was more than $10.0 \%$ (Table 2), indicating that deposition, substrate adsorption, and microbial action had certain effects on the removal of TP. However, the $\mathrm{P}$ removal rate of $T$. angustifolia was as high as $88 \%$, which was similar to the results of Vincent et al. (2012). The P removal rate of $C$. dactylon 'Tifton 85 ' and $C$. selloana 'Pumila' was close or higher than that of $T$. angustifolia, suggesting that the plant absorption and assimilation accounted for most of $\mathrm{P}$ removal. However, the $\mathrm{P}$ removal rate of $C$. selloana 'Silver Comet' was only $28.2 \%$ and $34.4 \%$ in high and medium-concentration eutrophic water, and the contribution of $\mathrm{P}$ absorption was both lower than $67 \%$, indicating that the purification effect of $C$. selloana 'Silver Comet' was poor, which may be related to its low biomass and growth rates (Table 2).

The removal of COD in sewage mainly depends on the absorption of plants and the metabolism of microorganisms, and has a close relationship with oxygen. Therefore, cattails and other aquatic plants have a strong ability to remove organic matter, which is related to their well-developed aeration tissue (Nilratnisakorn et al., 2009). In this study, the COD removal rate of $C$. dactylon 'Tifton 85' and $C$. selloana 'Pumila' was slightly higher than that of $T$. angustifolia, indicating that the two plants also have a strong ability to remove organic matter. However, whether this is related to aerenchyma, and how well aerenchyma works in the actual wetland system, needs to be further tested. In addition, even though the highest COD purification rate of the four plants was about $70 \%$ (Table 1), there were still a lot of organic matter that were difficult to remove. The reason may be that some organics in the eutrophic water are not easily degraded by microorganism (Vymazal and Kröpfelová, 2009).

Our results showed that the removal rates of TP and TN decreased with the increase of eutrophic water concentration, and the reduction degree was different for different plants, which was similar to the results of previous study (Ling et al., 2012). However, the COD removal rate of plants treated with high-concentration eutrophic water was higher than that treated with medium-concentration eutrophic water. The results of Tanner (2001) also showed that there was a significant linear relationship $\left(R^{2}>0.99\right)$ between the influent organic matter load and the organic matter removal in plant and plant-free wetlands. This is mainly because organic matter acts as carbon source and energy for microbial metabolism, and the microorganisms are more active under high-concentration treatment conditions, thus the removal rate of organic matter is relatively high (Liu et al., 2012).

\section{Conclusions}

1) Compared with the control water, all four plants can effectively remove $\mathrm{NH}_{4}{ }^{+}-\mathrm{N}$, $\mathrm{NO}_{3}{ }^{-}-\mathrm{N}, \mathrm{TN}, \mathrm{TP}$, and COD from eutrophic water. 2) C. dactylon 'Tifton 85' showed the fastest and the highest purification effect on the removal of $\mathrm{NH}_{4}{ }^{+}-\mathrm{N}, \mathrm{NO}_{3}{ }^{-}-\mathrm{N}, \mathrm{TN}, \mathrm{TP}$, and COD. The purification effect of C. selloana 'Pumila' was closer to or higher than that of T. angustifolia. C. selloana 'Silver Comet' has the lowest purification effect. 3) C. dactylon 'Tifton 85 ' and C. selloana 'Pumila' also have higher accumulation and contribution rate of $\mathrm{N}, \mathrm{P}$ absorption, which may be directly related to their rapid growth. 4) The concentration of pollutants in water affects the removal rate of $\mathrm{N}, \mathrm{P}$, and COD by plants.

\section{Literature Cited}

Bouchama, K., R. Rouabhi, and M. Reda Djebar. 2016. Behavior of Phragmites australis (CAV.) Trin. Ex Steud used in phytoremediation of wastewater contaminated by cadmium. Desalin. Water Treat. 57(12):5325-5330, https://doi.org/ $10.1080 / 19443994.2015 .1022001$.
Fonseca, A., A.J. Melfi, F.A. Monteiro, C.R Montes, V. Almeida, and U. Herpin. 2007. Treated sewage effluent as a source of water and nitrogen for tifton 85 bermudagrass. Agr. Water. Manage. 87(3):328-336, https:// doi.org/10.1016/j.agwat.2006.08.004.

Gersberg, R.M., B.V. Elkins, S.R. Lyon, and C.R. Goldman. 1986. Role of aquatic plants in wastewater treatment by artificial wet-lands. Water Res. 20(3):363-368, https://doi.org/ 10.1016/0043-1354(86)90085-0.

Ghosh, D. and B. Gopal. 2010. Effect of hydraulic retention time on the treatment of secondary effluent in a subsurface flow constructed wetland. Ecol. Eng. 36(8):1044-1051, https://doi. org/10.1016/j.ecoleng.2010.04.017.

Jóźwiakowski, K., M. Gajewska, A. Pytka, M. Marzec, M. Gizińska-Górna, A. Jucherski, A. Walczowski, M. Nastawny, A. Kamińska, and S. Baran. 2017. Influence of the particle size of carbonate-siliceous rock on the efficiency of phosphorous removal from domestic wastewater. Ecol. Eng. 98:290-296, https://doi.org/ 10.1016/j.ecoleng.2016.11.006.

Li, H., L. Liu, Y. Lou, T. Hu, and J. Fu. 2011. Genetic diversity of Chinese natural bermudagrass (Cynodon dactylon) germplasm using ISSR markers. Scientia Hort. 127(4):555-561, https://doi.org/10.1016/j.scienta.2010.12.001.

Li, X., H. Xi, X. Sun, Y. Yang, S. Yang, Y. Zhou, X. Zhou, and Y. Yang. 2015. Comparative proteomics exploring the molecular mechanism of eutrophic water purification using water hyacinth (Eichhornia crassipes). Environ. Sci. Pollut. R. 22(11):8643-8658, https://doi.org/ 10.1007/s11356-014-4020-3.

Lian, H., Q. Lei, X. Zhang, H. Yen, H. Wang, L. Zhai, H. Liu, H. Jr-Chuan, T. Ren, and J. Zhou. 2018. Effects of anthropogenic activities on long-term changes of nitrogen budget in a plain river network region: A case study in the Taihu Basin. Sci. Total Environ. 645:1212-1220, https://doi.org/10.1016/j.scitotenv.2018.06.354.

Lim, T.K. 2007. Edible medicinal and non medicinal plants. Springer, Netherlands, https://doi.org/ 10.1007/978-94-007-5653-3.

Ling, Z., J.R. Yang, and Z.N. Lu. 2012. Research on the effect of sewage concentration on treatment efficiency of constructed wetlands. Adv. Mat. Res. 356-360:1510-1515, https://doi.org/ 10.4028/www.scientific.net/AMR.356-360.1510.

Liu, C., G.H. Ning, L.L. Lü, Y.H. Wu, Y.L. Yan, S. Yin, and J.Z. Xie. 2012. Removal of COD in duck wastewater and capacity estimation in Baiyangdian Lake based on a simulated reed 
wetland system. Acta. Scie. Circums. (in Chinese with English abstract) 32(9):2119-2125, https://doi.org/10.13671/j.hjkxxb.2012.09.007.

Lu, B., Z.S. Xu, J.G. Li, and X.L. Chai. 2018. Removal of water nutrients by different aquatic plant species: An alternative way to remediate polluted rural rivers. Ecol. Eng. 110:18-26, https://doi.org/10.1016/j.ecoleng.2017.09.016.

Lu, R.K. 2000. The analysis method of soil and agro-chemistry. Agricultural Scientech Press, Beijing, China (in Chinese).

Lu, S., X. Zhang, J. Wang, and L. Pei. 2016. Impacts of different media on constructed wetlands for rural household sewage treatment. J. Clean. Prod. 127(127):325-330, https://doi.org/ 10.1016/j.jclepro.2016.03.166.

Meng, X., Z.M. Xu, T. Zhu, Z. Ning, L. Hao, and G. Ding. 2018. Photosynthetic dynamics and water use characteristics of ornamental grasses in summer of southern china. (in Chinese with English abstract) J. Fujian Agr. For. Univ. (Natural Science Edition) 47(2):167-173, https://doi. org/10.13323/j.cnki.j.fafu(nat.sci.).2018.02.007.

Muhammad, G., A. Mehmood, M. Shahid, R.S. Ashraf, M. Altaf, M.A. Hussain, and M.A. Raza. 2020. Biochemical methods for water purification. In: M.I. Inamuddin Ahamed, E. Lichtfouse, and A.M. Asiri (eds.). Methods for bioremediation of water and wastewater pollution. Environmental chemistry for a sustainable world, Vol. 51. Springer, Cham, Switzerland, https://doi.org/10.1007/978-3-030-48985-4_8.

Nilratnisakorn, S., P. Thiravetyan, and W. Nakbanpote. 2009. A constructed wetland model for synthetic reactive dye wastewater treatment by narrow-leaved cattails (Typha angustifolia Linn.). Water Sci. Technol. 60(6):1565-1574, https://doi.org/10.2166/wst.2009.500.

Ojoawo, S.O., G. Udayakumar, and P. Naik. 2015. Phytoremediation of phosphorus and nitrogen with Canna $\mathrm{x}$ generalis reeds in domestic wastewater through NMAMIT constructed wetland. Aquat. Procedia 4:349-356, https://doi. org/10.1016/j.aqpro.2015.02.047.

Paredes, D., P. Kuschk, and H. Kser. 2010. Influence of plants and organic matter on the nitrogen removal in laboratory-scale model subsurface flow constructed wetlands inoculated with anaerobic ammonium oxidizing bacteria. Eng. Life Sci.
7(6):565-576, https://doi.org/10.4028/www. scientific.net/AMM.522-524.609.

Qin, B., W. Li, G. Zhu, Y. Zhang, T. Wu, and G. Gao. 2015. Cyanobacterial bloom management through integrated monitoring and forecasting in large shallow eutrophic Lake Taihu (China). J. Hazard. Mater. 287(28):356-363, https://doi. org/10.1016/j.jhazmat.2015.01.047.

Razmkhah, S., M.A. Mohammadifar, S.M.A. Razavi, and M.T. Ale. 2016. Purification of cress seed (Lepidium sativum) gum: Physicochemical characterization and functional properties. Carbohydr. Polym. 141:166-174, https:// doi.org/10.1016/j.carbpol.2015.12.071.

Rocio, F.S.J.M., C.B. Albornoz, K. Larsen, and R. Najle. 2018. Bioaccumulation of heavy metals in limnobium laevigatum and ludwigiapeploides: Their phytoremediation potential in water contaminated with heavy metals. Environ. Geol. 77:404.1-404.8, https://doi.org/10.1007/ s12665-018-7566-4.

Saber, A., M. Tafazzoli, S. Mortazavian, and D.E. James. 2018. Investigation of kinetics and absorption isotherm models for hydroponic phytoremediation of waters contaminated with sulfate. J. Environ. Manage. 207(1):276-291, https://doi.org/10.1016/j.jenvman.2017.11.039.

State Environmental Protection Administration of China. 2002. Monitoring method of water and wastewater. 4th ed. China Environmental Science Press, Beijing, China (in Chinese).

Tanner, C.C. 2001. Plants as ecosystem engineers in subsurface-flow treatment wetlands. Water Sci. Technol. 44(11-12):9-17, https://doi.org/ 10.2166/wst.2001.0804

The Ministry of Water Resources of the People's Republic of China. 2007. The technical specification for surface water resources quality assessment (SL395-2007). China Water \& Power Press, Beijing, China (in Chinese).

Vincent, G., C. Florent, K. Margit, and B. Jacques. 2012. Effect of plant species on water quality at the outlet of a sludge treatment wetland. Water Res. 46(16):5305-5315, https://doi.org/ 10.1016/j.watres.2012.07.007.

Vourlitis, G.L. and J.L. Kroon. 2013. Growth and resource use of the invasive grass, pampas grass (Cortaderia selloana), in response to nitrogen and water availability. Weed Sci. 61(1):117-125.

Vymazal, J. and L. Kröpfelová. 2009. Removal of organics in constructed wetlands with horizontal sub-surface flow: A review of the field experience. Sci. Total Environ. 407(13):3911-3922, https://doi.org/10.1016/j.scitotenv.2008.08.032.

Wei, Y. 2021. Application of artificial intelligence in the process of ecological water environment governance and its impact on economic growth. Math. Probl. Eng. 4:1-9, https://doi.org/10.1155/ 2021/9967531.

Wu, H., J. Zhang, R. Wei, S. Liang, C. Li, and H. Xie. 2013a. Nitrogen transformations and balance in constructed wetlands for slightly polluted river water treatment using different macrophytes. Environ. Sci. Pollut. Res. Int. 20(1):443-451, https://doi.org/10.1007/s11356-01 2-0996-8.

Wu, H.M., J. Zhang, C. Li, and J.L. Fan. 2013b. Mass balance study on phosphorus removal in constructed wetland microcosms treating polluted river water. CLEAN-Soil. Air. Water 41(9):844-850, https://doi.org/10.1002/clen. 201200408

Xu, J.T., C. Li, F. Yang, Z. Dong, J. Zhang, Y. Zhao, P. Qi, and Z. Hu. 2011. Typha angustifolia stress tolerance to wastewater with different levels of chemical oxygen demand. Desalination 280(1-3):58-62, https://doi.org/10.1016/j. desal.2011.06.050

Yao, M., Y.L. Li, X.D. Yang, and Q. Liu. 2011. Three-year changes in planktonic diatom communities in a eutrophic lake in Nanjing, Jiangsu Province, China. J. Freshwat. Ecol. 26(1):133-141, https://doi.org/10.1080/02705060. 2011.553932.

Zhang, Y.M., X.M. Bai, Y.F. Tian, and L.J. Gong. 2019. Description of anatomical traits of leaves and adaptability analysis of eight ornamental grasses. Acta. Agres. Sin. 27(5):1370-1376, https://doi.org/10.11733/j.issn.1007-0435.2019. 05.032. (in Chinese with English abstract).

Zhu, L., Z. Li, and T. Ketola. 2011. Biomass accumulations and nutrient uptake of plants cultivated on artificial floating beds in China's rural area. Ecol. Eng. 37(10):1460-1466, https://doi. org/10.1016/j.ecoleng.2011.03.010. 